\title{
Plasma insulin concentration is affected by body condition in Icelandic horses
}

\author{
Anna Jansson ${ }^{1,2}$, Gudrun Stefansdottir ${ }^{1,2^{*}}$, Juan Carlos Rey Torres ${ }^{1}$, Sveinn Ragnarsson ${ }^{2}$ \\ From Animal Obesity - causes, consequences and comparative aspects \\ Uppsala, Sweden. 14-16 June 2015
}

\section{Introduction}

Little is known about the variation in plasma insulin levels in Icelandic horses and factors that influence it.

\section{Objectives}

The aim was to describe the variation in plasma insulin levels in a group of healthy Icelandic horses showed at a breed evaluation field test (evaluation of gaits under rider and conformation) and to document possible relationships between insulin levels and sex, age, body weight, height, body condition score (BCS) and management such as subjective level of fitness, travel time and daily forage and concentrate allowance.

\section{Methods}

Data from 201 horses were collected (4-11 years). Body condition score was assessed using a 5-degree scale. A venous blood sample was taken before the gait test. Plasma insulin were analysed in duplicates by ELISA and between samples variation was $<10 \%$. ANOVA (mixed model) was used (effects considered significant at $\mathrm{p}<0.05)$.

\section{Results}

Plasma insulin levels ranged from 0.01 to $0.60 \mu \mathrm{g} / \mathrm{L}$. Concentrate allowance and BCS had a significant effect on the plasma insulin level. BCS ranged from 2.3 to 4.0 (approximately 4 to 7 on a 9-degree scale) and concentrate allowance from 0 to $4 \mathrm{~kg}$. For one degree of increase in BCS, log-insulin increased with $0.45 \mu \mathrm{g} / \mathrm{L}$ and for every kilo of increase in the concentrate allowance, log-insulin increased with $0.26 \mu \mathrm{g} / \mathrm{L}$.

\footnotetext{
* Correspondence: gudrunst@holar.is

'Department of Animal Nutrition and Management, Swedish University of Agricultural Sciences, Uppsala, Sweden

Full list of author information is available at the end of the article
}

\section{Conclusion}

In Icelandic horses considered to be fit for a breed evaluation field test, plasma insulin levels increased not only due to increased concentrate intake as could be expected, but also to a considerable extent due to an increase in BCS.

\section{Authors' details}

${ }^{1}$ Department of Animal Nutrition and Management, Swedish University of Agricultural Sciences, Uppsala, Sweden. ${ }^{2}$ Department of Equine Science, Holar University College, Holar, Iceland.

Published: 25 September 2015

\section{doi:10.1186/1751-0147-57-S1-O1}

Cite this article as: Jansson et al:: Plasma insulin concentration is affected by body condition in Icelandic horses. Acta Veterinaria Scandinavica 2015 57(Suppl 1):01.

\section{Submit your next manuscript to BioMed Central and take full advantage of: \\ - Convenient online submission \\ - Thorough peer review \\ - No space constraints or color figure charges \\ - Immediate publication on acceptance \\ - Inclusion in PubMed, CAS, Scopus and Google Scholar \\ - Research which is freely available for redistribution \\ Submit your manuscript at www.biomedcentral.com/submit}

